УДК 377/378.091-057.21:005.332.4

DOI:

Вікторія Жигірь, доктор педагогічних наук, професор професор кафедри професійної освіти, трудового навчання та технологій Бердянського державного педагогічного університету Олена Кривильова, доктор педагогічних наук, доцент доцент кафедри професійної освіти, трудового навчання та технологій Бердянського державного педагогічного університету

\title{
ПІДГОТОВКА КОНКУРЕНТОСПРОМОЖНИХ КВАЛІФІКОВАНИХ РОБІТНИКІВ ЯК МЕТА ЗАКЛАДІВ ПРОФЕСІЙНОЇ (ПРОФЕСІЙНО-ТЕХНІЧНОЇ) ОСВІТИ
}

У статті визначено актуальні проблеми професійної підготовки майбутніх кваліфікованих робітників у закладах професійної (професійно-технічної) освіти. Здійснено теоретичний аналіз сутності понять “конкурентоспроможність особистості”, “конкурентоспроможність випускника закладу професійної освіти”, особливостей і характеристик конкурентоспроможності майбутніх кваліфікованих робітників. Визначено основні напрями удосконалення професійної підготовки майбутніх конкурентоспроможних кваліфікованих робітників у закладах професійної (професійно-технічної) освіти.

Ключові слова: професійна підготовка майбутніх кваліфікованих робітників; заклад професійноӥ (професійно-технічної) освіти; конкурентоспроможність особистості; конкурентоспроможність випускника закладу професійної освіти; конкурентоспроможність майбутніх кваліфікованих робітників.

Jim. 18.

Victoria Zhigir, Doctor of Sciences (Pedagogy), Professor, Professor of the Professional Education, Labor Training and Technologies Department, Berdyansk State Pedagogical University

Olena Kryvylova, Doctor of Sciences (Pedagogy), Associate Professor, Associate Professor of the Professional Education,

Labor Training and Technologies Department, Berdyansk State Pedagogical University

\section{PREPARATION OF COMPETITIVE QUALIFIED WORKERS AS A GOAL OF PROFESSIONAL (PROFESSIONALAND TECHNICAL) EDUCATION INSTITUTIONS}

The article identifies current issues of professional training of future qualified workers in professional (professional and technical) education institutions.

Theoretical analysis of the essence of concepts "personality competitiveness", "competitiveness of a professional education institution graduate", as well as the features and characteristics of future qualified workers" competitiveness is carried out.

It was found that the training of future qualified workers should focus on the formation of their professional competence and in particular on the development of professionally and socially significant personality traits that will allow them to win the competition and ensure stable demand in the labor market. At the same time, the competitiveness of future qualified workers is a complex personal entity that integrates these professionally and socially significant personality traits.

The main directions of improving the professional training of future competitive qualified workers in professional (professional and technical) institutions are identified: development and implementation of mechanisms for timely detection of changes in production technologies and labor organization, study of employers' requirements for graduates' qualification through constant monitoring of work environment to update the content of education (educational and professional program, curricula); practice-oriented training of the profession through constant contact with employers and their participation in the educational process and certification of graduates, involvement of students in various activities; motivation to carry out professional activities through the use of active and interactive methods and modern teaching aids; creating conditions for the actualization of students' personal resources through the development of professionally and socially significant personality traits.

Keywords: professional training of future skilled workers; professional (professional and technical) education institution; competitiveness of personality; competitiveness of a professional education institution graduate;

$\Pi$ остановка проблеми. Реформування української системи професійної (професійно-технічної) освіти в аспекті ії

взаємовідносин з реальною економікою та ринком праці є наразі важливою державною проблемою. Про це наголошено в Концепції реалізації
(C)

В. Жигірь, О. Кривильова, 2021 


\section{ППДГОТОВКА КОНКУРЕНТОСПРОМОЖНИХ КВАЛІФІКОВАНИХ РОБІТНИКІВ ЯК МЕТАЗАКЛАДІВ ПРОФЕСІЙНОӤ (ПРОФЕСІЙНО-ТЕХНІЧНОӤ) ОСВІТ}

державної політики у сфері професійної (професійно-технічної) освіти “Сучасна професійна (професійно-технічна) освіта" на період до 2027 р. (2019). "Реформування системи професійної (професійно-технічної) освіти спрямовано на підготовку конкурентоспроможного та мобільного на ринку праці фахівця, особистості, яка здобула освітні та професійні компетентності відповідно до ऑï інтересів, здібностей, можливостей, потреб національної економіки та суспільства" [15].

Потреба ринку праці у компетентних кваліфікованих робітниках, здатних до творчого розвитку і самореалізації, готових ефективно діяти в умовах ринкової економіки, працювати на новій техніці та з новими виробничими технологіями, боротися за робочі місця та протистояти негативним тенденціям щодо зайнятості робітничого персоналу (скорочення робочих місць, робочого дня, тижня, заробітної платні тощо), має знайти адекватне відображення у змісті їхньої професійноїпідготовки. Відтак конкурентоспроможність майбутніх кваліфікованих робітників набуває статусу одного з пріоритетних показників роботи закладів професійної (професійно-технічної) освіти.

Аналіз останніх досліджень і публікацій. Проблему професійної підготовки майбутніх кваліфікованих робітників досліджено у працях В. Байденко, В.Бондаря, Ю. Зіньковського, О. Коваленко, І. Лікарчука, Л. Лук'янової, Е. Осовського, А. Селецького таін.

Різні аспекти формування конкурентоспроможності майбутніх фахівців у професійній освіті розкрито у працях Е. Габітової, О. Грішнової, О. Гущиної, С. Батишева, Р. Безсоліциної, А. Маркової, Л. Мітіної, Н. Ничкало, Б. Паригіна, В. Сліпчук, О. Філь, Е. Хайрулліної та ін.

Мета статті здійснити теоретичний аналіз сутності понять “конкурентоспроможність особистості”, “конкурентоспроможність випускника закладу професійної освіти”, особливостей і характеристик конкурентоспроможності майбутніх кваліфікованих робітників, а також визначити основні напрями удосконалення професійної підготовки майбутніх конкурентоспроможних кваліфікованих робітників в закладах професійної (професійнотехнічної) освіти.

Виклад основного матеріалу дослідження. Сучасний ринок праці ставить жорсткі вимоги перед випускниками закладів професійної (професійно-технічної) освіти. Наявність документа про освіту ще не гарантує їм отримання робочого місця за фахом. У деяких випадках для роботодавців важливий рівень кваліфікації або досвід роботи, в деяких - здатність реалізувати певний проєкт або вирішити складне виробниче завдання в умовах невизначеності. До того ж, імовірність отримати робоче місце більша в тих робітників, які мають творчий та інтелектуальний потенціал, які є “самодостатньою особистістю 3 адекватною самооцінкою, здатні самостійно приймати рішення, брати на себе відповідальність, проявляти ініціативу, ефективно взаємодіяти з оточуючими" [9, 22], тобто конкурентоспроможних.

На ринку праці конкурентоспроможність характеризує “основні властивості людського капіталу, що визначають міру задоволення ринкової потреби у праці” $[5,6]$. На підприємствах iii пов'язують із персоналом і визначають як сукупність конкурентних переваг персоналу підприємства (природних, освітньо-професійних, ділових, моральних якостей) і його здатність реалізувати ці переваги, що задовольняє одночасно потреби суспільства, підприємства та працівника [10; 16].

Стосовно “конкурентоспроможності особистості", унауковій літературі $€$ низка універсальних визначень цього терміна інтегральна характеристика, що являє собою сукупність якостей, які визначають здатність здійснювати певну діяльність більш ефективно за інших, що вигідно відрізняє людину від інших учасників конкуренції (Р. Безсоліцина) [3]; динамічна відкрита система, що розвивається на основі особистісної програми саморозвитку і дає можливість випускнику ефективно адаптуватися у світі праці (Е. Хайрулліна) [17]; “соціально орієнтована система здібностей, властивостей і якостей особистості, що характеризує їі потенційні можливості в досягненні успіху (навчанні, професійній i позапрофесійній діяльності)" (В. Голєамінова) [7, 251] та ін.

Останнім часом вживання терміна “конкурентоспроможність особистості" поширюється й на сферу професійної освіти, де під конкурентоспроможністю майбутніх робітників розуміють “сукупність професійних знань, умінь, навичок та особистісних якостей, що забезпечують кваліфікованому робітникові конкурентні переваги на ринку праці” (Н. Ничкало) [13]; здатність виграти в інших претендентів економічне змагання за працевлаштування на “добре” робоче місце за умови максимальної відповідності його професійної підготовки вимогам робочого місця та суб'єктивним уподобанням роботодавців (О. Борисова, Л. Міляєва) [4]; сукупність природних, освітньо-професійних, ділових та моральних якостей працівників, що найбільше користуються попитом у певний період ринкової кон'юнктури як такі, що допомагають 


\section{ПІДГОТОВКА КОНКУРЕНТОСПРОМОЖНИХКВАЛІФІКОВАНИХ РОБІТНИКІВ}

ЯКМЕТА ЗАКЛАДІВ ПРОФЕСІЙНОЇ(ПРОФЕСІЙНО-ТЕХНІЧНОӦ) ОСВІТ

якісно виконувати трудові завдання і в умовах конкуренції досягати кращої реалізації інтересів роботодавця (О. Смірнов) [16]; відносна й узагальнена характеристика випускника закладу професійної освіти, що є інтеграцією його професійної, соціальної та особистісної компетенцій, яка забезпечує йому впевненість у власних силах і здатність витримувати конкуренцію на ринку праці порівняно 3 випускниками аналогічних закладів освіти (Е. Габітова) [6]; “професіонал, готовий адекватно ситуації та часу знайти оптимальний і ефективний метод вирішення та виконання завдання" (Н. Корнейченко) $[11,211]$ та ін.

Конкурентоспроможність працівника на регіональному ринку праці О. Шубалий розглядає як “сукупність якостей, які проявляються у конкурентній боротьбі та мають кількісне й якісне вираження в показниках освіченості, професійнокваліфікаційної підготовки, мотивованості, ефективності праці, соціальної захищеності, які формують конкурентні переваги й уже повністю чи частково реалізовані, або можуть бути реалізовані у перспективі, задовольнивши конкретні запити роботодавців, а також спрямовані на досягнення особистих, організаційних цілей в контексті реалізації положень регіональної політики у сфері ринку праці” [18, 167-168].

Отже, аналіз поняття “конкурентоспроможність випускника закладу професійної освіти” дає підстави стверджувати, що підготовка майбутніх кваліфікованих робітників повинна орієнтуватися на формування у них професійної компетентності й зокрема на розвиток професійно- та соціальнозначущих якостей особистості, які дають можливість в конкурентній боротьбі та забезпечать стабільну затребуваність на ринку праці. При цьому конкурентоспроможність майбутніх кваліфікованих робітників є складним особистісним утворенням, яке інтегрує ці професійно- та соціально-значущі якості особистості.

Професійно-значущими якостями особистості конкурентоспроможного фахівця дослідники називають: високий рівень працездатності та прагнення до якісних кінцевих результатів праці, здатність долати труднощі, творче ставлення до справи, прагнення до професійного самовдосконалення, здатність до прийняття відповідальних, часом ризикованих рішень, ініціативність і самодисципліна, підприємливість і діловитість, здатність до самоаналізу та прийняття відповідальних рішень тощо $[7 ; 8 ; 11$; $16]$.
Соціально-значущимиякостямиконкурентоспроможного на ринку праці працівника $є$ : комунікабельність, здатність до захисту своїх прав і свобод, наполегливість у досягненні мети діяльності, креативність та ініціативність, здатність виявляти необхідні вольові зусилля для досягнення поставленої мети, уміння контролювати й коригувати власний емоційний стан, досягати емоційної врівноваженості, впевненість у собі, прагнення до підвищення кваліфікації і постійного професійного самовдосконалення, само презентабельність, власна гідність тощо [2; 7; 8].

Уважаємо за доречне також наголосити, що професійно- та соціально-значущі якості $\epsilon$ взаємопов'язаними бо саме вони характеризують єдиний процес розвитку особистості, який своєю чергою стимулює майбутніх кваліфікованих робітників до формування ціннісних орієнтацій і мотивації до праці, процесу навчання професії.

Таким чином, необхідність підготовки майбутніх конкурентоспроможних кваліфікованих робітників вимагає від закладів професійної (професійно-технічної) освіти відповідних змін в освітній діяльності. Ці зміни мають бути пов'язані, передовсім 3 переглядом освітньо-професійних програм, підвищенням якості підготовки випускників з позицій вимог ринку праці, створенням умов для розвитку творчої, активної особистості, здатної максимально реалізувати себе в професії.

На наше переконання, важливим вектором діяльності закладів професійної (професійнотехнічної) освіти має стати розробка та упровадження механізмів своєчасного виявлення змін у технологіях виробництва й організації праці, вивчення вимог роботодавців щодо кваліфікації випускників [1]. В цьому аспекті Н. Ничкало пропонує такі етапи діяльності закладів професійної (професійно-технічної) освіти: “орієнтація на постійний системний зв'язок 3 динамікою змін на ринку праці, секторами економіки та науково-технічним прогресом; педагогічне перетворення здобутих моніторингом матеріалів (визначення інноваційного навчального змісту і цілей освітньої діяльності в напрямі формування конкурентоспроможності учня, запровадження нових навчальних курсів, залучення відповідних ресурсів тощо)" $[13,143]$.

Значний потенціал у підготовці майбутніх кваліфікованих робітників до конкурентних перемог на ринку праці вбачаємо в практикозорієнованому навчанні, яке передбачає поєднання освітнього процесу в закладі професійної (професійно-технічної) освіти 3 практичною діяльністю учнів на профільному виробництві та 


\section{ПІДГОТОВКА КОНКУРЕНТОСПРОМОЖНИХ КВАЛІФІКОВАНИХ РОБІТНИКІВ ЯК МЕТАЗАКЛАДІВ ПРОФЕСІЙНОӤ(ПРОФЕСІЙНО-ТЕХНІЧНӦ̈) ОСВІТ}

орієнтацією цього процесу на кінцевий продукт формування та розвиток професійної компетентності [12; 14]. При цьому доцільно залучати учнів до різних видів діяльності (навчально-пізнавальна, навчально-професійна, квазіпрофесійна, творча, пошукова) під час проходження всіх видів практики.

У цьому аспекті також слід визначити важливість взаємодії закладів професійної (професійно-технічної) освіти з підприємствами та організаціями за такими напрямами як: участь роботодавців і провідних фахівців-практиків у розробці гнучких освітньо-професійних програм і навчальних планів (відповідно до вимог ринку праці та індивідуальних потреб особистості); залучення до викладання окремих дисциплін і проведення майстер-класів; проходження учнями виробничої практики на базі підприємств і організацій.

Значущим напрямом практико-орієнтованого навчання $є$ залучення роботодавців до оцінки якості всіх етапів професійної підготовки майбутніх кваліфікованих робітників. Представники сфери праці мають брати участь в оцінці результатів практичної підготовки учнів на виробництві, виступати експертами на конкурсах професійної майстерності, під час підсумкової кваліфікаційної атестації випускників.

Важливе значення для підготовки майбутніх конкурентоспроможних кваліфікованих робітників має мотивація до професійної діяльності. 3 цією метою в процесі теоретичної та практичної підготовки слід застосовувати активні й інтерактивні методи навчання (дискусія, тренінг, аналіз виробничих ситуацій, проєктний, “мозковий штурм”, модерація та ін.), сучасні засоби навчання (тренажери нового покоління, інформаційно-комунікаційні, мультимедійні та ін.).

Заради підвищення інтересу до професії та прагнення до самореалізації у ній потрібно проводити різноманітні заходи, спрямовані на усвідомлення учнями своїх професійних можливостей у певному професійному співтоваристві, перспектив подальшого професійного та кар'єрного зростання, розвитку навичок ефективної самопрезентації тощо. Крім того, учням слід розповідати про правила i алгоритми поводження на ринку праці в умовах конкуренції, про особливості та проблеми працевлаштування.

Об'єктивною потребою у професійній підготовці майбутніх конкурентоспроможних кваліфікованих робітників є створення умов для актуалізації їх особистісних ресурсів, а саме професійно- та соціально-значущих якостей особистості. Вважаємо за необхідне приділяти особливу увагу організації різних видів позанавчальної діяльності учнів (громадська, волонтерська, творча, науково-дослідницька та ін.) з метою розвитку громадянської активності та освоєння учнями низки соціальних ролей.

Висновки і перспективи подальших розвідок. Таким чином, професійна підготовка майбутніх кваліфікованих робітників у закладах професійної (професійно-технічної) освіти має відповідати реаліям часу, потребам суспільства та мусить базуватися на: розробці впровадженні механізмів своєчасного виявлення змін у технологіях виробництва й організації праці, вивченні вимог роботодавців до кваліфікації випускників через постійний моніторинг виробничого середовища для оновлення змісту навчання (освітньо-професійна програма, навчальні плани); практико-зорієнованому навчанні професії через постійний зв'язок 3 роботодавцями та їх участю в освітньому процесі й атестації випускників, залученні учнів до різних видів діяльності; мотивації до здійснення професійної діяльності через застосування активних й інтерактивних методів і сучасних засобів навчання; створенні умов для актуалізації особистісних ресурсів учнів через розвиток професійно- та соціально-значущих якостей особистості.

Перспективи подальших досліджень убачаємо в дослідженні методичних аспектів професійної підготовки майбутніх кваліфікованих робітників у закладах професійної (професійно-технічної) освіти.

\section{ЛІТЕРАТУРА}

1. Белорусов Е.А. Актуализация и интеграция личностных ресурсов студента в профессиональную деятельность как фактор подготовки конкурентоспособного специалиста. Профессиональное образование и рынок труда. 2017. № 4. С. 58-63.

2. Бережний В., Кравчук Ю., Дешко Т. Конкурентоспроможність кваліфікованої робочої сили - основна вимога ринку праці. Руснаука: сайт. URL: http://www.rusnauka.com/11_EISN_2010/ Economics/63928.doc.htm (дата звернення 27.07.2021).

3. Бессолицина Р.В. Инновационные подходы к организации научно-методической работы. Мemoдucm. 2010. №1. С. 25-27.

4. Борисова О.В., Миляева Л.Г. Основные направления повышения конкурентоспособности выпускников на рынке труда. Известия Иркутской государственной экономической академии. 2009. №5 (67). С. 157-161. 


\section{ПІДГОТОВКА КОНКУРЕНТОСПРОМОЖНИХ КВАЛІФІКОВАНИХ РОБІТНИКІВ ЯК МЕТА ЗАКЛАДІВ ПРОФЕСІЙНОЇ(ПРОФЕСІЙНО-ТЕХНІЧНОӤ) ОСВІТ}

5. Брусєнцева О.А. Конкурентоспроможність персоналу як складова конкурентоспроможності підприємства. Науковий вісник УМО. Серія. Економіка та управління. 2017. Випуск 3. С. 2-12.

6. Габитова Э.М. Основные качества конкурентоспособного специалиста. Подготовка конкурентоспособного специалиста как цель современного образования: материалы международнойнаучно-практической конференции. 2021 ноября 2011 года. г. Пенза - Улан-Удэ - Семей. Россия: Научно-издательский центр “Социосфера”, 2011. С. 59-60.

7.ГолеминоваВ.М.Подготовкаконкурентоспособного специалиста как цель современного образования. Обеспечение качества профессионального образования как основной фактор подготовки конкурентоспособного специалиста: материалы региональной научно-практической Интернетконференции. Ливны, Россия, 15 декабря 2017 г. Орел: Орловский государственный университет имени И.С. Тургенева. 2018. С. 250-254.

8.ГрішноваО.,ШпиркоО. Конкурентоспроможність персоналу підприємства: критерії визначення та показники вимірювання. Украӥна: аспекти npaųi. 2004. № 3. C. 3-9.

9. Гущина О. М. Система подготовки конкурентоспособного выпускника на основе формирования профессиональной компетенции. Карельский научный журнал. Педагогические науки. 2016. Т. 5. № 4(17). С. 20-23.

10. Коломієць В.М. Місце конкурентоспроможності персоналу в системі трудових відносин підприємства. Економіка та підприємницттво. Держава та регіони. 2006. №4. С. 169-172.

11. Корнейченко Н.В. Конкурентоспособность будущого специалиста как показатель качества его подготтовки. Вестник АГТУ. 2007. № 6 (41). C. 208-214.

12. Майковська В.І. Практико-оріснтоване навчання як засіб професіоналізації підготовки майбутніх фахівців в Україні. Проблеми інженерно-педагогічної освіти. 2016. № 50-51. C. 161-167.

13. Ничкало Н.Г. Професійна освіта і навчання: проблеми взаємозв'язку з ринком праці. Формування широкої кваліфікації робітників. Вклад ПТО у розвиток трудового потенціалу XXI століття : збірник матеріалів, підготовлених у рамках реалізації укр.-нім. проекту “Підтримка реформи професійно-технічної освіти в Україні” / Ю. Вайс, Н. Ничкало, А. Сімак та ін. Ніжин: Аспект-Поліграф, 2007. С. 134-148.

14. Петренко Л.М. Практико-орієнтований підхід до формування змісту підвищення кваліфікації педагогів за дистанційною формою.
Методичні засади підвищення кваліфікаціі педагогічних працівників системи професійноі освіти: збірник матеріалів Всеукраїнської Інтернетконференції. Хмельницький. 2016. С. 465-469.

15. Про схвалення Концепції реалізації державної політики у сфері професійної (професійно-технічної) освіти єСучасна професійна (професійно-технічна) освітає на період до 2027 року: розпорядження Кабінету Міністрів України від 12 червня 2019 року № 419-р. Урядовий кур'єр . 2019. 26 червня. с. 1.

16. СмірновО.О.Підвищенняконкурентоспроможності персоналупромисловихпідприємств. Автореф. дис... канд. екон. наук: 08.00.07. НАН України. Ін-т демографії та соц. дослідж. Київ, 2007. 20 с.

17. Хайруллина Э.Р. Системная ориентация проектно-творческой деятельности на саморазвитие конкурентоспособности студентов инженеров-технологов. Казань: Центр инновационных технологий, 2007.348 c.

18. Шубалий О.М. Теоретичні засади дослідження конкурентоспроможності працівників на регіональному ринку праці. Економічний форум. 2017. №2. C. 164-170.

\section{REFERENCES}

1. Belorusov, Ye.A. (2017). Aktualizatsiya i integratsiya lichnostnykh resursov studenta $\mathrm{v}$ professionalnuyu deyatelnost kak faktor podgotovki konkurentosposobnogo spetsialista [Actualization and integration of student's personal resources into professional activity as a factor in the preparation of a competitive specialist]. Professional education and labor market. No. 4, pp. 58-63. [in Russian].

2. Berezhnyi, V., Kravchuk, Yu. \& Deshko, T. (2021). Konkurentospromozhnist kvalifikovanoi robochoi syly - osnovna vymoha rynku pratsi [Competitiveness of skilled labor is the main requirement of the labor market]. Available at: http:/ /www.rusnauka.com/11_EISN_2010/Economics/ 63928.doc.htm (Accessed 4 July 2020) [in Ukrainian].

3. Bessolitsina, R.V. (2010). Innovatsionnye podkhody $\mathrm{k}$ organizatsii nauchno-metodicheskoy raboty [Innovative approaches to the organization of scientific and methodological work]. Methodist. No.1, pp. 25-27. [in Russian].

4. Borisova, O.V. \& Milyaeva, L.G. (2009). Osnovnye napravleniya povysheniya konkurentosposobnosti vypusknikov na rynke truda [The main directions of increasing the competitiveness of graduates in the labor market]. Bulletin of the Irkutsk State Economic Academy. No.5 (67), pp. 157 161. [in Russian].

5. Brusientseva, O.A. (2017). Konkurentospromozhnist 


\section{ПІДГОТОВКА КОНКУРЕНТОСПРОМОЖНИХ КВАЛІФІКОВАНИХ РОБТТНИКІВ ЯК МЕТА ЗАКЛАДІВ ПРОФЕСІЙНОӤ(ПРОФЕСІЙНО-ТЕХНІЧНӦ̈) ОСВІТ}

personalu yak skladova konkurentospromozhnosti pidpryiemstva [Competitiveness of personnel as a component of competitiveness of the enterprise]. Scientific Bulletin of UMO. Series. Economics and management. Vol. 3, pp. 2-12. [in Ukrainian].

6. Gabitova, E.M. (2011). Osnovnye kachestva konkurentosposobnogo spetsialista [The main qualities of a competitive specialist]. Training of a competitive specialist as the goal of modern education: Proceedings of the Conference Title. November 2021, Penza - Ulan-Ude - Semey. (pp. 59 60). Russia: Scientific Publishing Center "Sociosphere". [in Russian].

7. Goleminova, V.M. (2018). Podgotovka konkurentosposobnogo spetsialista kak tsel sovremennogo obrazovaniya [Training of a competitive specialist as the goal of modern education]. Ensuring the quality of vocational education as the main factor in the training of a competitive specialist: Proceedings of the Conference Title. Livny, Russia, December 15, 2017 (pp. 250 254). Orel: Oryol State University named after I.S. Turgenev. [in Russian].

8. Hrishnova, O. \& Shpyrko, O. (2004). Konkurentospromozhnist personalu pidpryiemstva: kryterii vyznachennia ta pokaznyky vymiriuvannia [Competitiveness of enterprise personnel: criteria for determination and measurement indicators]. Ukraine: aspects of work. No.3, pp. 3-9 [in Ukrainian].

9. Gushchina, O.M. (2016). Sistema podgotovki konkurentosposobnogo vypusknika na osnove formirovaniya professionalnoy kompetentsii [The system of training a competitive graduate based on the formation of professional competence]. Karelian scientific journal. Pedagogical Sciences. Vol. 5. No. 4(17), pp. 20 23. [in Russian].

10.Kolomiiets, V.M.(2006).Mistsekonkurentospromozhnosti personalu v systemi trudovykh vidnosyn pidpryiemstva [The place of staff competitiveness in the system of labor relations of the enterprise]. Economics and entrepreneurship. State and regions. No.4, pp. 169-172. [in Ukrainian].

11. Korneychenko, N.V.(2007). Konkurentosposobnost budushchogo spetsialista kak pokazatel kachestva ego podgottovki [Competitiveness of a future specialist as an indicator of the quality of his training]. Bulletin of $A S T U$. No. 6 (41), pp. 208-214. [in Russian].

12. Maikovska, V.I. (2016). Praktyko-oriientovane navchannia yak zasib profesionalizatsii pidhotovky maibutnikh fakhivtsiv v Ukraini [Practical-oriented training as a means of professionalization of training of future specialists in Ukraine]. Problems of engineering and pedagogical education. No. 5051.pp. 161-167. [in Ukrainian].

13. Nychkalo, N.H. (2007). Profesiina osvita i navchannia: problemy vzaiemozviazku z rynkom pratsi [Profesional education and training: problems of the relationship with the labor market]. Formation of a broad qualification of workers. Abstracts of the project "Support to the reform of vocational education in Ukraine". Nizhyn: Aspect-Polygraph, pp. 134148 [in Ukrainian].

14. Petrenko L.M., (2016). Praktyko-oriientovanyi pidkhid do formuvannia zmistu pidvyshchennia kvalifikatsii pedahohiv za dystantsiinoiu formoiu [Practice-oriented approach to the formation of the content of professional development of teachers by distance learning]. Methodical bases of advanced training of pedagogical workers of system of professional education: Proceedings of the Conference Title, pp. 465-469. [in Ukrainian].

15. Pro skhvalennia Kontseptsii realizatsii derzhavnoi polityky u sferi profesiinoi (profesiinotekhnichnoi) osvity "Suchasna profesiina (profesiinotekhnichna) osvita" na period do 2027 roku: rozporiadzhennia Kabinetu Ministriv Ukrainy vid 12 chervnia 2019 roku № 419-r. [Concepts for the implementation of state policy in the field of vocational (vocational) education "Modern vocational (vocational) education" for the period up to 2027]. Government courier. 26 June, p. 1. [in Ukrainian].

16. Smirnov, O.O. (2007). Pidvishchennya konkurentospromozhnosti personalu promislovikh pidpriiemstv [Improving the competitiveness of industrial personnel]. Extended abstract of candidate's thesis. 08.00.07. NAS of Ukraine. Inst. of Demography and Soc. research. Kyiv, 20 p. [in Ukrainian].

17. Khayrullina, E.R. (2007). Sistemnaya orientatsiya proektno-tvorcheskoy deyatelnosti na samorazvitie konkurentosposobnosti studentov inzhenerov-tekhnologov [Systemic orientation of design and creative activity on the self-development of the competitiveness of students of process engineers]. Kazan: Center for Innovative Technologies, 348 p. [in Russian].

18. Shubalyi, O.M. (2017). Teoretychni zasady doslidzhennia konkurentospromozhnosti pratsivnykiv na rehionalnomu rynku pratsi [Theoretical bases of research of competitiveness of workers in the regional labor market]. Economic forum. No.2, pp. 164-170. [in Ukrainian].

Стаття надійшла до редакції 19.08.2021

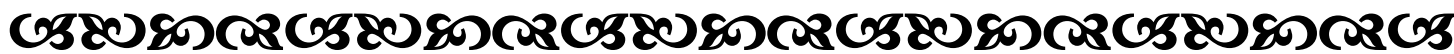

